J. Perinat. Med. 14 (1986) 235

\section{Maternal and fetal endocrine stress response at vaginal delivery with and without an epidural block}

\author{
Magnus Westgren¹, Sten G. E. Lindahl ${ }^{2}$, and Nils E. Nordén ${ }^{3}$ \\ ${ }^{1}$ Department of Obstetrics and Gynecology, Karolinska Institutet, Danderyd \\ Hospital, Danderyd, Sweden \\ ${ }^{2}$ Department of Anesthesiology, Mayo Clinic, Rochester, U.S.A. \\ ${ }^{3}$ Department of Clinical Chemistry, University Hospital, Lund, Sweden
}

\section{Introduction}

During normal vaginal delivery a marked increase in maternal stress hormones is known to occur [8]. Several studies have shown that the maternal stress response during labor could be modified by an epidural block $[2,3,22]$. The influence of epidural analgesia on the fetal endocrine stress response during labor and vaginal delivery is still under debate. In recent studies of cesarean sections performed under epidural anesthesia it has been shown that comparatively high levels of fetal stress hormones occurred suggesting an unaffected capacity of the fetus to respond to stress $[6,14]$.

The purpose of the present investigation was to further elucidate the effect of an epidural block on maternal and fetal stress hormones in normal parturients at vaginal delivery.

\section{Patients and methods}

Nineteen healthy patients were studied. All had a spontaneous onset of labor and had reached full term. Ten patients received either on request, or on the recommendation of the obstetrician present, an epidural block (group EA). Nine patients (group NEA) used nitrous oxide on demand for pain relief.

\section{Curriculum vitae}

MAgnus Westgren, $M . D$., Ph. D. was born in Stockholm in 1950. He graduated from University of Lund in 1974 where he later received his specialist training at the Department of Obstetrics and Gynecology. From 1984-1985 he was a visiting research fellow at the Women's Hospital, University of Southern

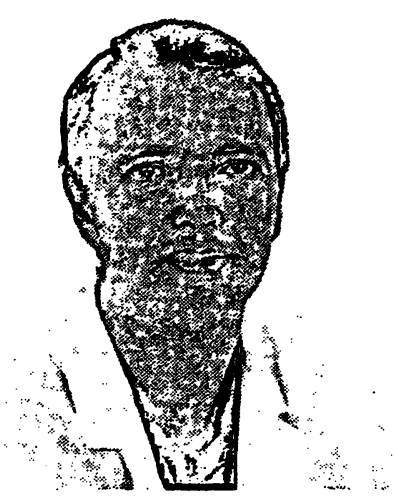
California, Los Angeles. Since 1985 he is holding a position as an associate professor at the Karolinska Institutet, Danderyd Hospital, Danderyd. His main research interest is in the field of fetal physiology.

\subsection{Obstetrics}

On admittance to the delivery ward all patients were in the first stage of labor with a cervical dilatation of less than $4 \mathrm{~cm}$. Seven patients in group EA and 3 in group NEA were primiparae (see: table I). During labor routine electronic fetal monitoring (Hewlett Packard 8030 A) was performed via a scalp electrode. Intrapartum surveillance and criteria for assessment of fetal heart rate (FHR) tracings have been described previously [24]. 


\subsection{Anesthesia}

In the women who received an epidural block the epidural space was entered between the first and second lumbar vertebrae. An epidural catheter was inserted and a bolus of $6-8 \mathrm{ml}$ of $0.25 \%$ bupivacaine was injected. Then the epidural analgesia was maintained by intermittent doses ( 5 to $6 \mathrm{ml}$ ) of bupivacaine during the first stage of labor. During the second stage of labor a pudendal block of, in total, $20 \mathrm{ml} 0.25 \%$ bupivacaine was given in all cases. No top-up of the epidural analgesia was given during the last 30 minutes before delivery in any case. In the NEA group pain relief during the first stage of labor was achieved by $\mathrm{N}_{2} \mathrm{O}$ in $\mathrm{O}_{2}\left(\mathrm{FiO}_{2}\right.$ set at 0.5 ). No narcotics were given in this group. During the second stage of labor all women in this group also received a pudendal block of $20 \mathrm{ml} 0.25 \%$ bupivacaine.

\subsection{Biochemistry}

Blood samples for the analysis of ACTH and corticosteroids were collected in test-tubes containing EDTA $(10.5 \mathrm{mg} / 7 \mathrm{ml}$ blood) and aprotinin* (3000 KIE/7 ml blood) which had been prechilled in ice water. The samples were kept at $0^{\circ} \mathrm{C}$ until centrifugation in a refrigerated centrifuge. The resulting plasma was then stored at $-20^{\circ} \mathrm{C}$. ACTH levels were determined by radioimmunoassay (ACTHK, Sorin Biomedica, Italy) using rabbit antiserum raised against porcine ACTH coupled to bovine serum albumin. Human ACTH was used as a standard and ${ }^{125} \mathrm{I}-\mathrm{ACTH}$ as a tracer. The coefficient of variation in duplicate determinations was $17 \%$ for values $<50 \mathrm{ng}^{-1}$ and $10 \%$ for values $>$ $50 \mathrm{ng} \mathrm{l}^{-1}$. Cortisol levels were determined using a solid phase radioimmunoassay (Gammacoat, Clinical Assays, Mass., USA) with rabbit anticortisol serum attached to the test-tubes and binding protein and ${ }^{125} \mathrm{I}$-cortisol as tracer. The coefficient of variation was $<7 \%$. The crossreactivity was $88 \%$ for prednisolone and was insignificant for other steroids tested. A ra-

\footnotetext{
* Trasylol ${ }^{\circledR}$, Bayer, West Germany
}

** OHPK, Sorin Biomedica, Italy dioimmunochemical method was used for the assay of 17- $\alpha$-hydroxyprogesterone**. The method was based on rabbit antibodies against the 3-conjugate to bovine serum albumin. The tracer was tritiated and dextran-coated charcoal was used for separation.

Samples used for the determination of the total catecholamine concentration were drawn in test-tubes with $20 \mu \mathrm{l}$ anticoagulant and antioxidant (EGTA $90 \mathrm{mg} / \mathrm{ml}$, glutathione $60 \mathrm{mg} / \mathrm{ml}$ and $\mathrm{pH} 6.0-7.4)$ per $\mathrm{ml}$ blood. A modification of the radioenzymatic method of PASSON and Peuler [20] based on rat liver catechol-O-methyltransferase and S-adenosyl-L-methionine( ${ }^{3} \mathrm{H}$-methyl) was used. After periodate oxidation the resulting ${ }^{3} \mathrm{H}$-vanillin was extracted and measured by liquid scintillation. The "betweenruns" coefficient of variation for the assay was $4.7-6.5 \%$ depending on concentration. Normal values for adults are $0.8-2.4 \mathrm{nmol} \mathrm{1}^{-1}$.

\subsection{Measurements}

Blood samples were withdrawn from peripheral veins. Maternal blood samples were taken at delivery and 30 minutes after delivery for determination of the plasma concentration of ACTH, cortisol, 17- $\alpha$-hydroxyprogesterone (17 OHP), blood glucose (BG) and catecholamines (CA). Immediately following delivery double clamping of the umbilical cord was performed and a blood sample for the same analysis was taken from the umbilical vein.

\subsection{Statistics}

For the evaluation of the results unpaired Student's t-test was performed. P-values above 0.05 were not regarded as statistically significant.

\section{Results}

Obstetric and neonatal data for the two groups are presented in table I. There were more primiparae in the EA group than in the NEA group, and the duration of labor was longer in the 
Table I. Obstetric and neonatal data for the epidural and non-epidural group.

\begin{tabular}{|c|c|c|}
\hline & $\begin{array}{l}E A \\
n=10\end{array}$ & $\begin{array}{l}\text { NEA } \\
n=9\end{array}$ \\
\hline $\begin{array}{l}\text { Parity } \\
\text { Primipara } \\
\text { Multipara }\end{array}$ & $\begin{array}{l}7 \\
3\end{array}$ & $\begin{array}{l}3 \\
6\end{array}$ \\
\hline $\begin{array}{l}\text { Duration of labor } \\
\text { 1st stage }{ }^{+} \text {minutes (mean } \pm \text { SEM) } \\
\text { 2nd stage minutes (mean } \pm \text { SEM) }\end{array}$ & $\begin{array}{r}131 \pm 23 \\
99 \pm 18\end{array}$ & $\begin{array}{r}102 \pm 23 \\
54 \pm 22\end{array}$ \\
\hline $\begin{array}{l}\text { Fetal heart rate* } \\
\text { Normal baseline }(110-150 \mathrm{bpm}) \\
\text { Tachycardia }(>150 \mathrm{bpm}) \\
\text { Normal variability }(10-25 \mathrm{bpm}) \\
\text { Decreased variability }(<10 \mathrm{bpm}) \\
\text { Variable deceleartions }\end{array}$ & $\begin{array}{l}7 \\
3 \\
7 \\
3 \\
4\end{array}$ & $\begin{array}{l}9 \\
-8 \\
1 \\
3\end{array}$ \\
\hline Gestational age weeks (mean $\pm S D$ ) & $39.6 \pm 1.7$ & $40.1 \pm 1.7$ \\
\hline Birthweight, g. (mean \pm SD) & $3411 \pm 442$ & $3715 \pm 273$ \\
\hline $\begin{array}{l}\text { Apgar scores } \\
1 \text { minute, } 8-10 \\
5 \text { minutes, } 10\end{array}$ & $\begin{array}{l}10 \\
10\end{array}$ & $\begin{array}{l}9 \\
9\end{array}$ \\
\hline
\end{tabular}

EA group. Deviating fetal heart rate patterns occurred more often in the EA group, but in none of the patients were signs of intrapartum asphyxia found. The two groups were comparable with respect to birthweight and gestational age. Apgar scores were 8 or more at one minute in all cases, and at five minutes all had an Apgar score of 10.

\subsection{Maternal plasma concentrations}

The mean values ( \pm SEM) of blood analysis in the EA and NEA group are presented in table II. In the EA as well as in the NEA group mean values ( \pm SEM) of ACTH, $17 \mathrm{OHP}$ and $\mathrm{CA}$ at delivery were higher than 30 minutes after delivery. Plasma concentrations of cortisol and blood glucose were virtually unchanged.

Mean values ( \pm SEM) for maternal plasma concentrations of ACTH and cortisol were increased at delivery in the NEA group compared with the EA group ( $p<0.05$ and $p<0.05$, respectively, figure 1). There were no statisti- cally significant differences between plasma concentrations in the EA and NEA group for 17 OHP, blood glucose and CA.

\subsection{Umbilical plasma concentrations}

There were no significant differences in plasma concentrations (mean \pm SEM) of ACTH, cortisol, 17 OHP, blood glucose and CA between the two groups studied. Mean values were, however, slightly lower for ACTH and CA in the NEA group.

Catecholamine levels, showed a slight positive correlation to the duration of the second stage of labor ( $r=0.51, p<0.02)$ but not to different FHR patterns. No such positive correlation could be demonstrated for cortisol.

\subsection{Maternal and umbilical plasma concentra- tions}

In both the EA and in the NEA group plasma concentrations (mean \pm SEM) of ACTH and 


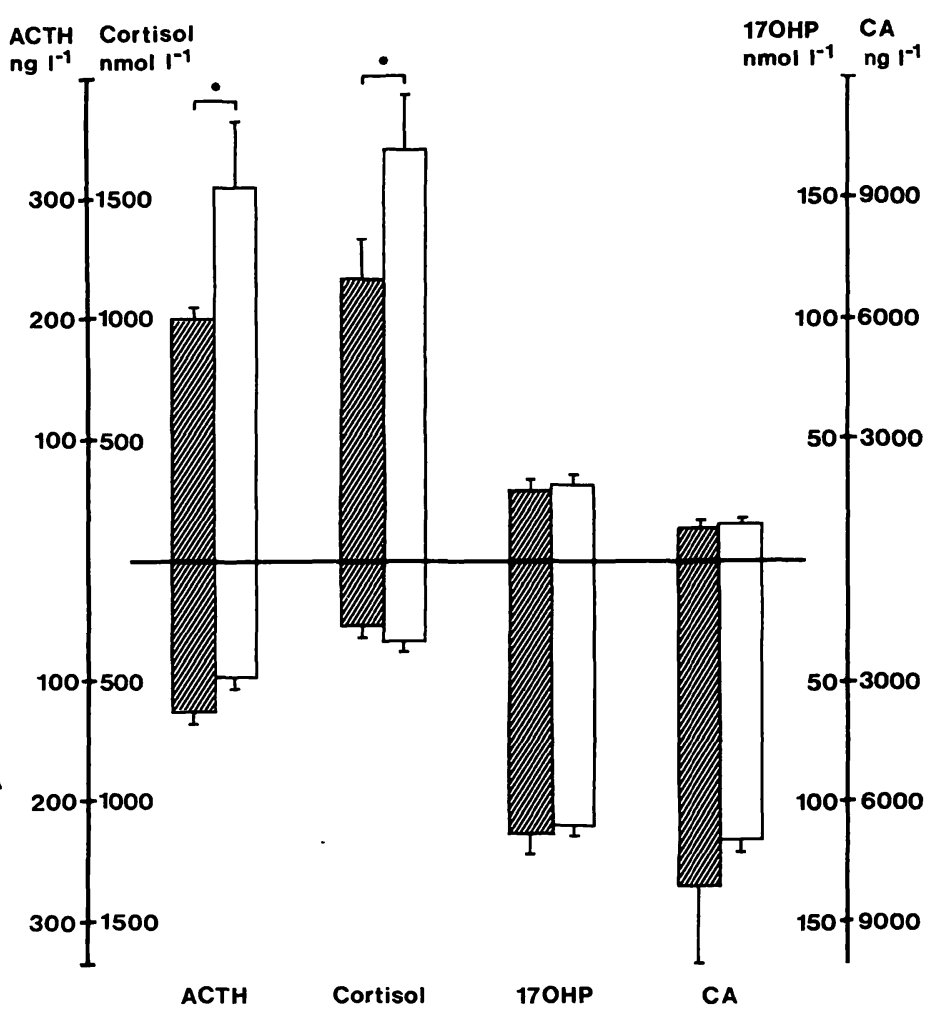

Figure 1. Plasma concentration (mean \pm SEM) for ACTH, cortisol, 17- $\alpha$-hydroxyprogesterone (17 OHP) and catecholamines (CA) in maternal blood at delivery (above the abscissa) and in umbilical vein blood (below the abscissa) in the epidural (filled bars) and the nonepidural group (unfilled bars).

cortisol were significantly lower in umbilical vein blood than in maternal blood at delivery $(\mathrm{p}<0.02, \mathrm{p}<0.001$, respectively, in the EA and $\mathrm{p}<0.01, \mathrm{p}<0.001$, respectively, in the NEA group, figure 1). For all patients the umbilical vein cortisol concentration showed a close linear relation to the maternal cortisol concentration $(r=0.82, p<0.001)$.

In umbilical vein blood the concentration of 17 OHP was 4 times higher in the EA group and 3 times higher in the NEA group compared with maternal blood ( $p<0.05$ and $p<0.05$, respectively). Mean values ( \pm SEM) of plasma concentration of CA were more than 10 times higher in umbilical vein blood than in maternal blood in the EA group $(p<0.001)$ and about 8 times higher in the NEA group $(p<0.001$, figure 1). No correlation between maternal and fetal CA concentrations could be demonstrated.

\section{Discussion}

The present study was designed to evaluate the influence of epidural anesthesia on maternal and fetal endocrine stress in normal parturients. In agreement with previous work it was found that an epidural block prevented the maternal cortisol surge which normally occurs in labor [2]. It was also shown in the present study that the pain relief obtained by epidural block led to a significantly lower ACTH concentration suggesting that the mechanism by which cortisol decreases is related to the hypothalamopituitary axis. Catecholamines were slightly lower in the EA group despite the fact that primipara and prolonged duration of labor, two factors known to be associated with high levels of CA [12], occurred more often in this group of patients. SHNIDER et al. [22] have recently shown that the maternal CA levels and predominantly epinephrine are reduced after epidural anesthesia. Elevation of epinephrine in maternal blood during labor is associated with pain and anxiety [12] suggesting that the alleviation of maternal pain is the mechanism by which epidural block decreases the maternal CA levels during labor.

The linear relation between maternal and umbilical vein cortisol concentrations regardless of whether an epidural block had been used or not, observed in the present study supports the hypothesis that the cortisol increase in fetal plasma during labor is of maternal origin [17, 21]. The 5 fold higher plasma cortisol level in maternal blood allows the suggestion of a diffusion passage over the placenta from mother to fetus. The lower plasma cortisol at delivery in group EA compared with in group NEA might have been the reason for the observed tendency towards a lower ACTH level in umbilical vein blood in group EA than in group NEA (table II). However, in the case of fetal asphyxia several authors have reported high venous cord blood cortisol concentrations indicating a fetal endogenic secretion $[7,8,15]$. Further work is required to determine the origin of the fetal cortisol surge at asphyxia, but an epidural block seems to be an adequate way 
Table II. Maternal and umbilical vein plasma concentrations (mean \pm SEM) of ACTH, cortisol, 17- $\alpha$-hydroxyprogesterone (17 OHP), glucose and catecholamines (CA) in the epidural and non-epidural group.

\begin{tabular}{lccccc}
\hline & ACTH & Cortisol & 17 OHP & Glucose & CA \\
\hline Maternal vein blood at delivery & & & & & \\
$\quad$ Epidural & $200 \pm 24$ & $1174 \pm 170$ & $27.9 \pm 2.4$ & $5.0 \pm 0.2$ & $815 \pm 109$ \\
$\quad$ Non epidural & $318 \pm 47^{*}$ & $1710 \pm 189^{*}$ & $31.4 \pm 2.4$ & $5.6 \pm 0.4$ & $911 \pm 138$ \\
$\quad$ Maternal vein blood 30 minutes after delivery & & & & & \\
$\quad$ Epidural & $88 \pm 12$ & $1328 \pm 157$ & $18.5 \pm 1.0$ & $5.0 \pm 0.3$ & $483 \pm 73$ \\
$\quad$ Non epidural & $116 \pm 25$ & $1637 \pm 161$ & $21.4 \pm 3.1$ & $5.5 \pm 0.4$ & $518 \pm 75$ \\
$\quad$ Umbilical vein blood & & & & & \\
$\quad$ Epidural & $123 \pm 22$ & $258 \pm 51$ & $117 \pm 11$ & $4.1 \pm 0.4$ & $8094 \pm 2137$ \\
$\quad$ Non-cpidural & $98 \pm 11$ & $327 \pm 69$ & $111 \pm 17$ & $4.3 \pm 0.3$ & $6948 \pm 2624$ \\
\hline
\end{tabular}

$*=\mathrm{p}<0,05$ for the difference between the epidural and non-epidural groups.

of reducing the maternal influence on the fetal cortisol levels.

Epidural anesthesia in normal parturients does not seem to influence the fetal endocrine stress variables evaluated in the present study. The observed differences in maternal blood cortisol concentrations between the two groups were not observed for the fetuses despite a linear individual relationship. This discrepancy was most probably due to the lower fetal cortisol concentrations. Moreover, 17 OHP which is almost entirely produced by the placenta [16, 23] was not influenced by the pain relief.

The fetal sympathoadrenal system plays an important role in the physiological events that adapt the fetus to stress. High levels of venous as well as arterial umbilical cord blood CA have been observed after vaginal delivery, and especially in association with fetal acidosis [11, 18].

Catecholamine concentrations in venous cord blood originate mainly from fetus since there

\section{Summary}

Maternal and fetal stress response at vaginal delivery werc studied in 19 normal parturients at term. Ten patients to whom an cpidural block (group EA) had been administrated were compared with 9 patients is little if any transplancental passage [19]. The roughly tenfold higher concentration is in accordance with previous studies $[10,13]$. In agreement with two recently published reports $[1,4]$ we found that epidural anesthesia did not influence the fetal CA levels in umbilical cord vein blood.

In conclusion, it was demonstrated that epidural anesthesia reduces the maternal stress hormones at delivery. An epidural block seems to have little or no effect on the fetal endocrine stress hormones as reflected by plasma concentrations in venous umbilical cord blood. The biological significance of these findings is open to discussion. Failure to raise the maternal stress hormones in labor seems to have no detrimental effect on mother or fetus. Conversely, epidural block is supposed to be beneficial to the fetus since low maternal levels of CA are associated with increased uterine blood flow $[5,9]$. In addition, the preserved ability of the fetus to respond to stress during labor after epidural block ought to be a prerequisite for a normal adaptation after birth. (group NEA) who used only nitrous oxide for pain rclief. Plasma concentrations of ACTH, cortisol, 17- $\alpha$ hydroxyprogesterone, blood glucose and catccholamincs were measured in maternal and umbilical vein blood at 
delivery and in maternal vein blood 30 minutes after delivery. At delivery maternal plasma concentrations of $\mathrm{ACTH}$, cortisol and catecholamines were lower in the EA group compared with in the NEA group. There were no differences in umbilical plasma concentrations of the studied stress variables between the two groups. A linear relation was demonstrated between maternal and umbilical vein cortisol concentration.
In both the EA and NEA group a significant fall in ACTH, 17- $\alpha$-hydroxyprogesterone and catecholamine concentrations were demonstrated 30 minutes after delivery, whereas cortisol and blood glucose were virtually unchanged.

It was found that epidural anesthesia reduced the maternal stress hormones at delivery but seemed to have little or no effect on the fetal endocrine stress hormones.

Keywords: Epidural block, fetal endocrine stress, maternal endocrine stress, vaginal delivery.

\section{Zusammenfassung}

Maternale und fetale „Stresshormon“-Ausschüttung bei vaginaler Entbindung mit bzw. ohne Periduralanästhesie

$\because$ Bei 19 unkomplizierten Spontangeburten am Termin untersuchten wir die mütterliche und fetale Stressreaktion auf eine vaginale Entbindung. 10 Patientinnen hatten eine Periduralanästhesie (PDA); sie wurden verglichen mit 9 Frauen, die zur Schmerzerleichterung lediglich Lachgas erhalten hatten. Wir bestimmten die Plasmakonzentrationen von ACTH, Kortisol, 17- $\alpha$-Hydroxyprogesteron, Glukose und Katecholaminen im maternalen und umbilikalen Venenblut unter der Geburt sowie im mütterlichen Blut nochmals 30 Minuten post partum. Unter der Geburt waren die Werte für ACTH, Kortisol und Katecholamine in der PDA-Gruppe niedri- ger als in der Gruppe ohne PDA. Bezüglich der Konzentrationen im Nabelvenenblut gab es zwischen den beiden Gruppen keine Unterschiede. Die Kortisolkonzentrationen im mütterlichen bzw. umbilikalen Venenblut zeigten eine lineare Abhängigkeit.

30 Minuten post partum kam es sowohl in der Gruppe mit wie ohne PDA zu einem signifikanten Abfall der ACTH-, 17- $\alpha$-Hydroxyprogesteron- und Katecholaminkonzentration. Dagegen blieb der Kortisol- und Glukosespiegel im wesentlichen unverändert.

Unsere Ergebnisse zeigen, daß bei einer Entbindung mit PDA die mütterlichen Stresshormone reduziert sind. Wenig bzw. keinen Einfluß hat eine PDA jedoch auf die fetale, hormonelle Stressreaktion.

Schlüsselwörter: fetale „Stresshormon“-Ausschüttung, mütterliche „Stresshormon“-Ausschüttung, Periduralanästhesie, vaginale Entbindung.

\section{Résumé}

Réponse endocrinienne de stress maternel et fotal lors de l'accouchement par voie basse avec ou sans analgésie péridurale

On a étudié la réponse maternelle et fotale lors de l'accouchement par voie basse chez 19 parturientes normales à terme. Parmi celles-ci, 10 ont reçu une analgésie péridurale (groupe EA) et ont été comparées aux 9 autres patientes (groupe NEA) qui n'utilisaient que le «nitrous oxide» pour le soulagement de la douleur. On a déterminé les concentrations plasmatiques d'ACTH, de cortisol, de 17-alpha-hydroxyprogestérone, de glucose et en catécholamines chez la mère et au niveau de la veine ombilicale à l'accouchement et 30 minutes après l'accouchement au niveau du sang veineux maternel. A l'accouchement, les concentrations plasmatiques maternelles d'ACTH, de cortisol et de catécholamines étaient infé- rieures dans le groupe EA en comparaison avec le groupe NEA. Il n'y avait pas de différence dans les concentrations plasmatiques ombilicales des variables étudiées du stress entre les deux groupes.

On a démontré une relation linéaire entre la concentration de cortisol chez la mère et dans la veine ombilicale. Une chute significative de l'ACTH, de la 17-alphahydroxyprogestérone et des catécholamines a été démontrée 30 minutes après l'accouchement à la fois dans le groupe EA et dans le groupe NEA, tandis que le cortisol et la glycémie sont demeurés pratiquement inchangés.

On a trouvé que l'analgésie péridurale réduit le stress maternel hormonal à l'accouchement mais qu'elle semble n'avoir qu'un effet minime ou nul sur les hormones du stress endocrinien du fœetus.

Mots-clés: Accouchement par voie basse, analgésie péridurale, stress fœtal endocrinien, stress maternel endocrinien. 


\section{References}

[1] Bistoletti P, L Nylund, H Lagercrantz, P HJemDAHL, H STRÖM: Fetal scalp catecholamines during labor. Am J Obstet Gynecol (1985) in press

[2] BUChAN PC, MK MiLNe, MCK BRownING: The effect of continuous epidural blockade on plasma 11-hydroxycorticosteroid concentrations in labour. J Obstet Gynaecol Br Cwth 80 (1973) 974

[3] Dimsdale JE, J Moss: Plasma catecholamines in stress and exercise. JAMA 243 (1980) 340

[4] FALCONER AD, DM LAKE: Circumstances influencing umbilical cord plasma catecholamines at delivery. Br J Obstet Gynaecol 89 (1982) 44

[5] Hollmen AI, R Jouppila, P Jouppila, A Koivulo, $H$ VIEROLA: Effect of extradural analgesia using bupivacaine and 2-chloroprocaine on intervillous blood flow during normal labour. Br J Anaesth 54 (1982) 837

[6] Irestedt L, H Lagercrantz, P HJemdahl, $\mathrm{K}$ HÄGNEVIK, P BELFRAGE: Fetal and maternal plasma catecholamine levels at elective cesarean section under general or epidural anesthesia versus vaginal delivery. Am J Obstet Gynecol 142 (1982) 1004

[7] IsHERWOOD DM, DM JENKINS, LA PERRY: Effects of delivery on fetal unbound cortisol concentration. Obstet Gynecol 57 (1981) 215

[8] JOLIVET A, H BlaNCHIER, JP GAUTRAY: Blood cortisol variations during late pregnancy and labour. Am Obstet Gynecol 119 (1974) 775

[9] Jouppila P, R Jouppila, A Hollmen, A Koivula: Lumbar epidural analgesia to improve intervillous blood flow during labor in severe preeclampsia. Obstet Gynecol 158 (1982) 161

[10] KaneOKa T, H Ozono, U Goto: Plasma nor-adrenalin and adrenalin concentrations in feto-maternal blood. Their relations to feto-maternal endocrine levels, cardiotocographic and mechanocardiographic values, and umbilical blood biochemical profiling. J Perinat Med 7 (1979) 302

[11] LagerCRANTZ H, P Bistolettr: Catecholamine release in the newborn infant at birth. Pediatr Res 11 (1977) 889

[12] Lederman RP, E Lederman, BA Work, D MCCANN: The relationship of maternal anxiety, plasma catecholamines, and plasma cortisol to progress in labor. Am J Obstet Gynecol 132 (1978) 459

[13] Leonetti G, C Bianchini, GB Picottr: Plasma catecholamines and plasma renin activity at birth and during the first day of life. Clin Sci 59 (1980) 319
[14] Lindahl S, N Norden, G Nybell-Lindahl, M WESTGREN: Endocrine stress response during general and epidural anaesthesia for elective caesarean sections. Acta Anaesthesiol Scand 27 (1983) 50

[15] Martinsen K, J Petola, L Tervilä, A Virtanen: Umbilical cord cortisol and arterial pH levels in spontaneous and induced labors. Obstet Gynecol 59 (1982) 171

[16] Mathur RS, S Landgrebe, LO Moody, S Powell, HO WILlIAMSON: Plasma steroid concentrations in maternal and umbilical circulation after spontaneous onset of labor. J Clin Endocrinol Metab $51(1980) 1235$

[17] Orhlander S, G Gennser, P Eneroth: Plasma cortisol levels in human fetus during parturition. Obstet Gynecol 48 (1976) 381

[18] Padbury JF, B Roberman, TH Oddie, CJ Hobel, DA FISHER: Fetal catecholamine release in response to labor and delivery. Obstet Gynecol 60 (1982) 607

[19] Parvez S, H ParveZ: Placental transfer of [H] epinephrine and its metabolites to the fetal heart during variable hormone treatments. Horm Res 5 (1974) 321

[20] Passon PG, JD Peuler: A simplified radiometric assay for plasma norepinephrine and epinephrine. Anal Biochem 51 (1973) 618

[21] Predine J, L Merceron, G Barrier, C Sureau, E Milgrom: Unbound cortisol in umbilical cord plasma and maternal plasma, a reinvestigation. Am J Obstet Gynecol 135 (1979) 1104

[22] Shnider SM, TK Abboud, R Artal, EH HeNRIKSEN, SJ STEFANI, G LEVINSON: Maternal catecholamines decrease during labor after lumbar epidural anesthesia. Am J Obstet Gynecol 147 (1983) 13

[23] TULCHINSKY D, HH SIMMER: Sources of plasma $17-$ hydroxyprogesterone in human pregnancy. J Clin Endocrinol Metab 35 (1972) 799

[24] Westgren M, E INGemarsson, I INGEMarsSon, T SoluM: Intrapartum electronic fetal monitoring in low-risk pregnancies. Obstet Gynecol 56 (1980) 301

Received July 4, 1985. Revised October 15, 1985. Accepted January 6, 1986.
Magnus Westgren, M. D., Ph. D.
Associate Professor
Karolinska Institutet
Department of Obstetrics and Gynecology
Dinderyd Hospital
S-18288 Danderyd, Sweden 